\title{
Synthesis, Crystal Structure and DNA-binding Properties of a Nickel(II) Complex with 2, 6-Bis(2-benzimidazolyl)pyridine
}

\author{
Huilu Wu, Xingcai Huang, Jingkun Yuan, Fan Kou, Guisheng Chen, Beibei Jia, Yang Yang, \\ and Yulin Lai \\ School of Chemical and Biological Engineering, Lanzhou Jiaotong University, Lanzhou 730070, \\ P. R. China \\ Reprint requests to Dr. Huilu Wu. E-mail: wuhuilu@163.com \\ Z. Naturforsch. 2010, 65b, 1334 -1340; received July 9, 2010

\begin{abstract}
A novel complex of nickel(II) picrate (pic) with the V-shaped ligand 2, 6-bis(2-benzimidazolyl)pyridine (bbp) was synthesized and characterized by elemental analysis, electrical conductivity, and IR and UV/Vis spectral measurements. The crystal structure of the nickel(II) complex $\left(\left[\mathrm{Ni}(\mathrm{bbp})_{2}\right](\mathrm{pic})_{2} \cdot 2 \mathrm{DMF}\right)$ has been determined by single-crystal X-ray diffraction. The Ni(II) cation is bonded to two bbp ligands through six nitrogen atoms, resulting in a distorted octahedral geometry. The DNA-binding properties of the nickel(II) complex were investigated by electronic absorption and fluorescence spectra and by viscosity measurements. The experimental results suggest that the nickel(II) complex binds to DNA in an intercalation mode.
\end{abstract}

Key words: 2,6-Bis(2-benzimidazolyl)pyridine, Nickel(II) Complex, Crystal Structure, DNA-binding Properties

\section{Introduction}

Transition metal complexes are used to bind and react at specific sequences of DNA for finding novel chemotherapeutics, probing DNA and developing highly sensitive diagnostic agents $[1,2]$. Therefore, an understanding of how these small molecules bind to DNA will be useful for the design of new drugs, diagnostic probes and reactive agents, which can recognize specific sites or conformations of DNA [2-4]. In addition, benzimidazoles and their derivates exhibit various remarkable biological activities as pharmaceuticals such as antitumor [5], antiviral [6], anticancer [7], antimicrobial [8], antiprotozoal [9], and anti-inflammatory or analgesic agents [10]. Metal ions and their complexes, because of their cationic character, three-dimensional structural profiles, and propensity for performing hydrolysis, redox, or photoreactions, have a natural aptitude for interacting with DNA [11]. An interesting concept for finding a complex with distinct biological and pharmaceutical features, the V-shaped system 2, 6-bis(2-benzimidazolyl)pyridine (bbp) was selected as a ligand to chelate nickel(II), which may enhance the interaction of the metal center(s) with DNA.
The interaction of transition metal complexes of the ligand bbp with DNA such as of ruthenium [12], copper [13], cobalt [14], chromium [15], and zinc [16] has been studied to have models of biological systems. In this paper, we report the synthesis, crystal structure, and DNA-binding properties of the Ni(II) picrate complex with bbp. The DNA-binding properties of the complex were investigated by spectrophotometric methods and viscosity measurements.

\section{Experimental Section}

Materials and physical measurements

Ethidium bromide (EB) and calf thymus DNA (CT-DNA) were obtained from Sigma Chemicals Co. (USA). Tris- $\mathrm{HCl}$ buffer solution was prepared using bidistilled water. Other reagents and solvents were reagent grade obtained from commercial sources and used without further purification. The solution of CT-DNA gave a ratio of UV absorbance at 260 and $280 \mathrm{~nm}, A_{260} / A_{280}$, of $1.8-1.9$, indicating that the DNA was sufficiently free of protein [17]. The stock solution of DNA $\left(2.5 \times 10^{-3} \mathrm{M}\right)$ was prepared in $5 \mathrm{mM}$ Tris- $\mathrm{HCl} / 50 \mathrm{mM}$ $\mathrm{NaCl}$ buffer $\left(\mathrm{pH}=7.2\right.$, stored at $4{ }^{\circ} \mathrm{C}$ and used within $4 \mathrm{~d}$ ). The DNA concentration was determined by measuring the UV absorption at $260 \mathrm{~nm}$, taking the molar absorption coefficient $\left(\varepsilon_{260}\right)$ of CT-DNA as $6600 \mathrm{M}^{-1} \cdot \mathrm{cm}^{-1}$ [18]. 
Elemental analyses were performed on a Carlo Erba 1106 elemental analyzer. IR spectra were recorded on a Bruker FT-IR Vertex 70 spectrometer in the range $4000-400 \mathrm{~cm}^{-1}$ using $\mathrm{KBr}$ pellets. Electrolytic conductance measurements were made with a DDS-11A-type conductivity bridge using a $10^{-3} \mathrm{~mol} \mathrm{~L}^{-1}$ solution in DMF at r.t. A glassy carbon working electrode, a platinum-wire auxiliary electrode, and a saturated calomel reference electrode (SCE) were used in the three-electrode measurements.

Electronic absorption spectra were taken on a Lab Tech UV Bluestar plus UV/Vis spectrophotometer. Using this method, the relative bindings of the complex to CT-DNA were studied in $5 \mathrm{mM}$ Tris- $\mathrm{HCl} / \mathrm{NaCl}$ buffer $(\mathrm{pH}=7.2)$. The sample solution was scanned in the range $200-500 \mathrm{~nm}$.

Fluorescence spectra were recorded on a 970CRT spectrofluorophotometer (Shanghai Precision \& Scientific Instrument Co., Ltd). While gradually adding a certain amount of DMF solution of the complex step by step to the EB-DNA solution in Tris- $\mathrm{HCl}$ buffer at $25^{\circ} \mathrm{C}$, the emission intensity at $520 \mathrm{~nm}$ was recorded. The sample solution was scanned in the range $550-750 \mathrm{~nm}$.

Viscosity experiments were conducted on an Ubbelodhe viscosimeter, immersed in a thermostated water-bath maintained at $25.0 \pm 0.1{ }^{\circ} \mathrm{C}$. DNA samples approximately $200 \mathrm{bp}$ in an average length were prepared by sonication in order to minimize complexities arising from DNA flexibility [19]. Titrations were performed for the compounds $(1-10 \mu \mathrm{M})$, and the complex was introduced into the CT-DNA solution $(50 \mu \mathrm{M})$ present in the viscometer. Data were presented as $\left(\eta-\eta_{0}\right)^{1 / 3}$ versus the ratio of the concentration of the compound to CT-DNA, where $\eta$ is the viscosity of CT-DNA in the presence of the complex, and $\eta_{0}$ is the viscosity of CTDNA alone. Viscosity values were calculated from the observed flow time of CT-DNA containing solutions corrected for the flow time of the buffer alone $\left(t_{0}\right)$ with the equation $\eta=\left(t-t_{0}\right) / t_{0}[20]$.

Preparation of 2,6-bis(2-benzimidazolyl)pyridine (bbp) and its nickel picrate complex

\section{2,6-Bis(2-benzimidazolyl)pyridine (bbp)}

The ligand bbp was synthesized according to the procedure reported by Addison [21]. M.p. $>300{ }^{\circ} \mathrm{C}$. The infrared and ${ }^{1} \mathrm{H}$ NMR spectra were almost consistent with those in the literature [21-23]. - IR $\left(\mathrm{KBr}\right.$, pellet, $\left.\mathrm{cm}^{-1}\right)$ : $v=3185 \mathrm{~s}\left(v_{\mathrm{N}-\mathrm{H}}\right), 1600 \mathrm{~m}\left(v_{\mathrm{C}-\mathrm{C}}\right), 1573 \mathrm{~s}\left(v_{\mathrm{C}=\mathrm{N}}\right), 1460 \mathrm{~s}$ $\left(v_{\mathrm{C}-\mathrm{N}}\right), 1434 \mathrm{~s}, 1319 \mathrm{~s}, 1278 \mathrm{~s}\left(v_{\mathrm{C}-\mathrm{N}}\right), 1230 \mathrm{~m}, 821 \mathrm{~m}, 742 \mathrm{vs}$ $\left(\delta_{\mathrm{Ph}(\mathrm{C}-\mathrm{H})}\right) .-{ }^{1} \mathrm{H}$ NMR $\left(400 \mathrm{MHz},\left[\mathrm{D}_{6}\right] \mathrm{DMSO}, 298 \mathrm{~K}\right)$ : $\delta=13.02(\mathrm{~s}, 2 \mathrm{H}, \mathrm{N}-\mathrm{H}), 8.36-8.38(\mathrm{~d}, J=7.59 \mathrm{~Hz}, 2 \mathrm{H}$, Py-H), $8.18-8.22$ (t, $J=7.46 \mathrm{~Hz}, 1 \mathrm{H}$, Py-H), 7.76-7.80 $(\mathrm{m}, J=7.83 \mathrm{~Hz}, 4 \mathrm{H}, \mathrm{Ph}-\mathrm{H}), 7.34-7.37$ (m, 4H, Ph-H). UV/Vis (DMF): $\lambda=300,345 \mathrm{~nm}$. $-\Lambda_{\mathrm{M}}$ (DMF, 297K): $1.41 \mathrm{~S} \cdot \mathrm{cm}^{2} \cdot \mathrm{mol}^{-1}$.
Table 1. Crystal data and structure refinement for [Ni(bbp $\left.)_{2}\right]-$ (pic) $2 \cdot 2 \mathrm{DMF}$.

\begin{tabular}{|c|c|}
\hline$\overline{\text { Complex }}$ & {$\left[\mathrm{Ni}(\mathrm{bbp})_{2}\right](\mathrm{pic})_{2} \cdot 2 \mathrm{DMF}$} \\
\hline Molecular formula & $\mathrm{C}_{56} \mathrm{H}_{44} \mathrm{~N}_{18} \mathrm{NiO}_{16}$ \\
\hline Molecular weight & 1283.80 \\
\hline Color, habit & yellow, block \\
\hline Crystal size, $\mathrm{mm}^{3}$ & $0.36 \times 0.25 \times 0.19$ \\
\hline Crystal system & monoclinic \\
\hline Space group & $P 2_{1} / n$ \\
\hline$a, \AA$ & $14.2087(3)$ \\
\hline$b, \AA$ & $26.5215(5)$ \\
\hline$c, \AA$ & $14.6989(3)$ \\
\hline$\beta, \operatorname{deg}$ & $93.7750(10)$ \\
\hline$V, \AA^{3}$ & $5527.06(19)$ \\
\hline Z & 4 \\
\hline$T, \mathrm{~K}$ & $153(2)$ \\
\hline$D_{\text {calcd }}, \mathrm{g} \mathrm{cm}^{-3}$ & 1.54 \\
\hline$\mu\left(\mathrm{MoK}_{\alpha}\right) \mathrm{mm}^{-1}$ & 0.4 \\
\hline$F(000), \mathrm{e}$ & 2648 \\
\hline$\theta$ range for data collection, deg & $3.01-27.48$ \\
\hline$h k l$ range & $\begin{array}{l}-18 \leq h \leq 18 \\
-34 \leq k \leq 32 \\
-18 \leq l \leq 19\end{array}$ \\
\hline Reflections collected / unique / $R_{\text {int }}$ & $4320 \overline{6} / 9 \overline{990} / 0.0377$ \\
\hline Data / restraints / parameters & $12544 / 16 / 814$ \\
\hline Final $R_{1} / w R_{2}$ indices $[I \geq 2 \sigma(I)]^{\mathrm{a}}$ & $0.0399 / 0.0920$ \\
\hline$R_{1} / w R_{2}$ indices (all data) ${ }^{\overline{\mathrm{b}}}$ & $0.0605 / 0.1062$ \\
\hline Goodness-of-fit ${ }^{\mathrm{c}}$ on $F^{2}$ & 1.108 \\
\hline Largest diff. peak / hole, e $\AA^{-3}$ & $0.72 /-0.60$ \\
\hline
\end{tabular}

\section{$\left[\mathrm{Ni}(\mathrm{bbp})_{2}\right](\mathrm{pic})_{2} \cdot 2 \mathrm{DMF}$}

To a stirred solution of 2, 6-bis(2-benzimidazolyl)pyridine $(0.1557 \mathrm{~g}, 0.50 \mathrm{mmol})$ in hot $\mathrm{MeOH}(10 \mathrm{~mL})$ was added $\mathrm{Ni}(\mathrm{pic})_{2}(0.1287 \mathrm{~g}, 0.25 \mathrm{mmol})$ dissolved in $\mathrm{MeOH}(5 \mathrm{~mL})$. Owing to the formation of the $\left[\mathrm{Ni}(\mathrm{bbp})_{2}\right]^{2+}$ complex, a paleyellow precipitate was generated immediately. The sediment was filtered off, washed with $\mathrm{MeOH}$ and absolute $\mathrm{Et}_{2} \mathrm{O}$, and dried in vacuo. The dried precipitate was dissolved in DMF to give a yellow solution, and yellow crystals suitable for X-ray diffraction studies were obtained by ether diffusion into the DMF solution after several days at r.t. Yield $0.1561 \mathrm{~g}, 55 \%$. Analysis for $\mathrm{C}_{56} \mathrm{H}_{44} \mathrm{~N}_{18} \mathrm{O}_{16} \mathrm{Ni}$ (1137.58): calcd. C 52.79, H 2.64, N 19.70; found C 52.25, H 2.74, N 20.15. - IR ( KBr, pellet, $\left.\mathrm{cm}^{-1}\right): v=3087 \mathrm{~s}\left(v_{\mathrm{N}-\mathrm{H}}\right), 1610 \mathrm{~s}$ $\left(v_{\mathrm{C}-\mathrm{C}}\right), 1566 \mathrm{~m}\left(v_{\mathrm{C}=\mathrm{N}}\right), 1494 \mathrm{~m}, 1460 \mathrm{~s}\left(v_{\mathrm{C}-\mathrm{N}}\right), 1436 \mathrm{w}$, $1363 \mathrm{~m}, 1317 \mathrm{~s}, 1272 \mathrm{~m}\left(v_{\mathrm{C}-\mathrm{N}}\right), 821 \mathrm{w}, 744 \mathrm{~s}\left(\delta_{\mathrm{Ph}(\mathrm{C}-\mathrm{H})}\right)$. UV/Vis (DMF): $\lambda=301,368,398 \mathrm{~nm} .-\Lambda_{\mathrm{M}}$ (DMF, 297K): $130.50 \mathrm{~S} \cdot \mathrm{cm}^{2} \cdot \mathrm{mol}^{-1}$.

\section{$X$-Ray structure determination of $\left[\mathrm{Ni}(\mathrm{bbp})_{2}\right](\mathrm{pic})_{2} \cdot 2 \mathrm{DMF}$}

A suitable single crystal was mounted on a glass fiber, and the intensity data were collected on a Rigaku R-axis Spider 
diffractometer with graphite-monochromatized $\mathrm{Mo} K_{\alpha}$ radiation $(\lambda=0.71073 \AA)$ at $153 \mathrm{~K}$. Data reduction and cell refinement were performed using RAPID AUTO programs [24]. The absorption correction was carried out empirically. The structure was solved by Direct Methods and refined by full-matrix least-squares calculations against $F^{2}$ using the SHELXTL software [25]. All $\mathrm{H}$ atoms were found in difference electron maps and were subsequently refined in a riding model approximation with $\mathrm{C}-\mathrm{H}$ distances ranging from 0.95 to $0.98 \AA$ and $U_{\text {iso }}(\mathrm{H})=1.2$ or $1.5 U_{\text {eq }}(\mathrm{C})$. The $\mathrm{H}$ atoms bonded to $\mathrm{N}$ atoms were refined independently with a distance constraint of $\mathrm{N}-\mathrm{H}=0.88 \AA$. The atoms of one DMF solvent molecule are disordered over two coplanar orientations with equal occupancy. A summary of parameters for the data collections and refinements is given in Table 1 .

CCDC 725540 contains the supplementary crystallographic data for this paper. These data can be obtained free of charge from The Cambridge Crystallographic Data Centre via www.ccdc.cam.ac.uk/data_request/cif.

\section{Results and Discussion}

The ligand bbp and the Ni(II) complex are stable in air and remarkably soluble in polar aprotic solvents such as DMF, DMSO and MeCN, slightly soluble in ethanol, methanol, ethyl acetate, and chloroform, and insoluble in water, $\mathrm{Et}_{2} \mathrm{O}$ and petroleum ether. The molar conductivities in DMF solution indicate that bbp $\left(1.41 \mathrm{~S} \cdot \mathrm{cm}^{2} \cdot \mathrm{mol}^{-1}\right)$ is a non-electrolyte, and the $\mathrm{Ni}(\mathrm{II})$ complex $\left(130.50 \mathrm{~S} \cdot \mathrm{cm}^{2} \cdot \mathrm{mol}^{-1}\right)$ is a $1: 2$ electrolyte [26].

\section{IR and electronic spectra}

The IR spectral data for the free ligand and the $\mathrm{Ni}$ (II) complex with their relative assignments have been studied to characterize their structures. The IR spectrum of the free ligand bbp shows characteristic absorption bands of the benzimidazole pyridine group at $1600,1573,1436$, and $1278 \mathrm{~cm}^{-1}$ assigned to $v(\mathrm{C}=\mathrm{C}), v(\mathrm{C}=\mathrm{N})$ and $v(\mathrm{C}-\mathrm{N})$, respectively [27-29]. For free bbp a strong band is found around $1573 \mathrm{~cm}^{-1}$ attributed to $v(\mathrm{C}=\mathrm{N})$ of the benzimidazole group, which becomes a medium band around $1564 \mathrm{~cm}^{-1}$ in the $\mathrm{Ni}(\mathrm{II})$ complex. The $v(\mathrm{C}=\mathrm{N})$ wavenumber of the ligand is blue-shifted by $10 \mathrm{~cm}^{-1}$ in the complex, which implies that all four imine nitrogen atoms are coordinated to the cation center. The free picrate anion shows IR bands at $908 \mathrm{~cm}^{-1}\left(v_{\mathrm{Ar}}\right)$ and $1271 \mathrm{~cm}^{-1}\left(v_{\mathrm{Ar}}(\mathrm{C}-\mathrm{OH})\right)$, which remain almost unchanged, but IR bands at $1365 \mathrm{~cm}^{-1}\left(v_{\mathrm{s}}\left(\mathrm{NO}_{2}\right)\right)$ and
Table 2. The electronic spectral data.

\begin{tabular}{llll}
\hline Compound & Solvent & Absorption (nm) & Band assignment \\
\hline Ligand (bbp) & DMF & 301,347 & $\pi \rightarrow \pi^{*}$ \\
Picric acid & DMF & $272,327,365$ & $\pi \rightarrow \pi^{*}$ \\
& & 419 & $n \rightarrow \pi^{*}$ \\
Nickel complex & DMF & 296,361 & $\pi \rightarrow \pi^{*}$ \\
& & 419 & $n \rightarrow \pi^{*}$ \\
& & - & $d \rightarrow d\left({ }^{3} \mathrm{~A}_{2 \mathrm{~g}} \rightarrow{ }^{3} \mathrm{~T}_{2 \mathrm{~g}}\right)$ \\
& & 555 & $d \rightarrow d\left({ }^{3} \mathrm{~A}_{2 \mathrm{~g}} \rightarrow{ }^{3} \mathrm{~T}_{1 \mathrm{~g}}(\mathrm{~F})\right)$ \\
& & 856 & $d \rightarrow d\left({ }^{3} \mathrm{~A}_{2 \mathrm{~g}} \rightarrow{ }^{3} \mathrm{~T}_{1 \mathrm{~g}}(\mathrm{P})\right)$ \\
\hline
\end{tabular}

$1544 \mathrm{~cm}^{-1}\left(v_{\mathrm{as}}\left(\mathrm{NO}_{2}\right)\right)$ of the free picrate anion are not split in half but slightly move to $1317 \mathrm{~cm}^{-1}\left(v_{\mathrm{s}}\left(\mathrm{NO}_{2}\right)\right)$ and $1566 \mathrm{~cm}^{-1}\left(v_{\mathrm{as}}\left(\mathrm{NO}_{2}\right)\right)$ for the $\mathrm{Ni}(\mathrm{II})$ complex, which indicates that the picrate anion is not coordinated but involved in forming intermolecular hydrogen bonds [29].

The electronic spectra of free bbp, picric acid and the $\mathrm{Ni}(\mathrm{II})$ complex were recorded at $298 \mathrm{~K}$ in $\mathrm{DMF}$ solution, and the data are given in Table 2. The ligand bbp shows two strong absorption bands at 301 and $347 \mathrm{~nm}$ attributed to $\pi \rightarrow \pi^{*}$ transitions. While picric acid shows four strong absorption bands at 272 , 327, 365 and $419 \mathrm{~nm}[30,31]$, the $\mathrm{Ni}(\mathrm{II})$ complex shows three strong absorption bands at 296, 361 and $419 \mathrm{~nm}$ for $\pi \rightarrow \pi^{*}$ and $n \rightarrow \pi^{*}$ transitions. The electronic spectra of $\mathrm{Ni}(\mathrm{II})$ complexes $\left(3 d^{8}\right)$ normally exhibit three weak $d$ - $d$ transitions, namely ${ }^{3} \mathrm{~A}_{2 \mathrm{~g}} \rightarrow{ }^{3} \mathrm{~T}_{2 \mathrm{~g}}$, ${ }^{3} \mathrm{~A}_{2 \mathrm{~g}} \rightarrow{ }^{3} \mathrm{~T}_{1 \mathrm{~g}}(\mathrm{~F}),{ }^{3} \mathrm{~A}_{2 \mathrm{~g}} \rightarrow{ }^{3} \mathrm{~T}_{1 \mathrm{~g}}(\mathrm{P})$ [32]. The title complex shows that two spin-allowed $\left({ }^{3} \mathrm{~A}_{2 \mathrm{~g}} \rightarrow{ }^{3} \mathrm{~T}_{1 \mathrm{~g}}(\mathrm{~F})\right.$, $\left.{ }^{3} \mathrm{~A}_{2 \mathrm{~g}} \rightarrow{ }^{3} \mathrm{~T}_{1 \mathrm{~g}}(\mathrm{P})\right)$ transitions at 555 and $856 \mathrm{~nm}$, respectively, and another weak $d$ - $d$ transition $\left({ }^{3} \mathrm{~A}_{2 \mathrm{~g}} \rightarrow{ }^{3} \mathrm{~T}_{2 \mathrm{~g}}\right)$ in the near-IR region hidden by other transitions.

\section{Molecular structure in the crystal}

Selected interatomic distances and bond angles of the complex $\left[\mathrm{Ni}(\mathrm{bbp})_{2}\right](\mathrm{pic})_{2} \cdot 2 \mathrm{DMF}$ are listed in Table 3 . The structure consists of a $\left[\mathrm{Ni}(\mathrm{bbp})_{2}\right]^{2+}$ cation (Fig. 1), two picrate anions, and two DMF solvate molecules. The metal ion, adopting a distorted octahedral geometry, is six-coordinated with an $\mathrm{N}_{6}$ ligand set of which four $\mathrm{N}$ atoms (N1, N4, N6, N9) are afforded by the the benzimidazole rings and the other two $(\mathrm{N} 4, \mathrm{~N} 8)$ by the pyridine rings. The bond angles of ideally $90^{\circ}$ range from $76.69(6)^{\circ}[\mathrm{N}(3)-$ $\mathrm{Ni}-\mathrm{N}(1)]$ to $110.07(6)^{\circ}[\mathrm{N}(3)-\mathrm{Ni}-\mathrm{N}(9)]$ and those of ideally $180^{\circ}$ from $153.14(6)^{\circ} \quad[\mathrm{N}(1)-\mathrm{Ni}-\mathrm{N}(4)]$ to $171.79(7)^{\circ}[\mathrm{N}(8)-\mathrm{Ni}-\mathrm{N}(3)]$. The shortest $\mathrm{Ni}-\mathrm{N}$ bond length is $2.0393(2) \AA\left[\mathrm{Ni}-\mathrm{N}_{\text {py }}(8)\right]$ and the longest is $2.1182(2) \AA\left[\mathrm{Ni}-\mathrm{N}_{\mathrm{bbp}}(4)\right]$. As a result of intermolec- 
Table 3. Selected interatomic distances $(\AA)$ and bond angles (deg) for the complex $\left[\mathrm{Ni}(\mathrm{bbp})_{2}\right](\mathrm{pic})_{2} \cdot 2 \mathrm{DMF}$.

\begin{tabular}{lclc}
\hline $\mathrm{Ni}-\mathrm{N}(8)$ & $2.0393(16)$ & $\mathrm{Ni}-\mathrm{N}(6)$ & $2.1128(16)$ \\
$\mathrm{Ni}-\mathrm{N}(3)$ & $2.0469(16)$ & $\mathrm{Ni}-\mathrm{N}(1)$ & $2.1134(17)$ \\
$\mathrm{Ni}-\mathrm{N}(9)$ & $2.1059(16)$ & $\mathrm{Ni}-\mathrm{N}(4)$ & $2.1182(16)$ \\
$\mathrm{N}(8)-\mathrm{Ni}-\mathrm{N}(3)$ & $171.79(7)$ & $\mathrm{N}(9)-\mathrm{Ni}-\mathrm{N}(1)$ & $95.38(6)$ \\
$\mathrm{N}(8)-\mathrm{Ni}-\mathrm{N}(9)$ & $77.21(6)$ & $\mathrm{N}(6)-\mathrm{Ni}-\mathrm{N}(1)$ & $92.78(6)$ \\
$\mathrm{N}(3)-\mathrm{Ni}-\mathrm{N}(9)$ & $110.07(6)$ & $\mathrm{N}(8)-\mathrm{Ni}-\mathrm{N}(4)$ & $107.44(6)$ \\
$\mathrm{N}(8)-\mathrm{Ni}-\mathrm{N}(6)$ & $77.17(6)$ & $\mathrm{N}(3)-\mathrm{Ni}-\mathrm{N}(4)$ & $77.22(6)$ \\
$\mathrm{N}(3)-\mathrm{Ni}-\mathrm{N}(6)$ & $95.78(6)$ & $\mathrm{N}(9)-\mathrm{Ni}-\mathrm{N}(4)$ & $87.60(6)$ \\
$\mathrm{N}(9)-\mathrm{Ni}-\mathrm{N}(6)$ & $154.02(6)$ & $\mathrm{N}(6)-\mathrm{Ni}-\mathrm{N}(4)$ & $96.09(6)$ \\
$\mathrm{N}(8)-\mathrm{Ni}-\mathrm{N}(1)$ & $99.23(6)$ & $\mathrm{N}(1)-\mathrm{Ni}-\mathrm{N}(4)$ & $153.14(6)$ \\
$\mathrm{N}(3)-\mathrm{Ni}-\mathrm{N}(1)$ & $76.69(6)$ & & \\
\hline
\end{tabular}

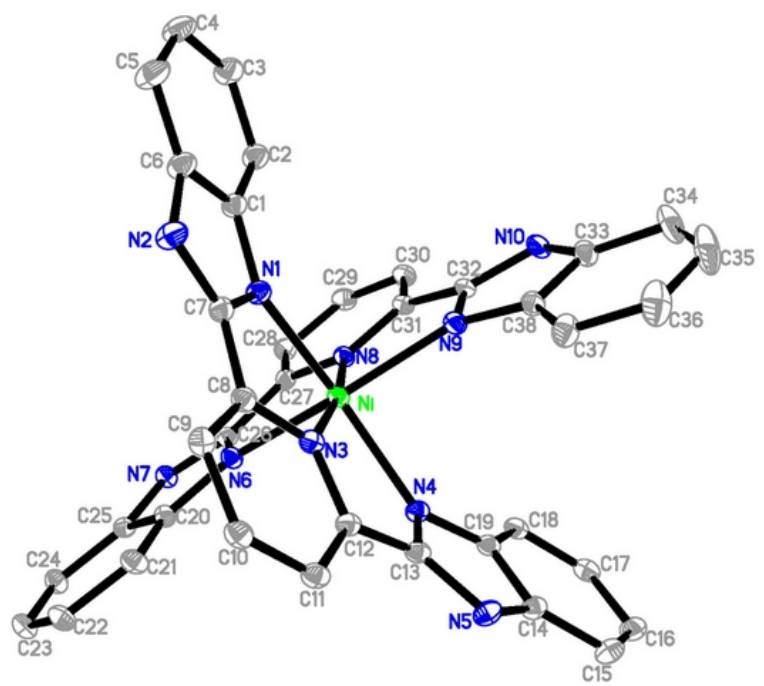

Fig. 1. Molecular structure of the $\left[\mathrm{Ni}(\mathrm{bbp})_{2}\right]^{2+}$ cation with displacement ellipsoids drawn at the $30 \%$ probability level; $\mathrm{H}$ atoms are omitted for clarity.

ular hydrogen bond contacts, the average bond length for $\mathrm{Ni}-\mathrm{N}_{\mathrm{bbp}}[2.1126(2) \AA]$ is longer than for $\mathrm{Ni}-\mathrm{N}_{\mathrm{py}}$ [2.0431(2) $\AA$ ]. With regard to a regular octahedron, the angles and bond lengths show some distortion (Fig. 1).

\section{DNA-binding properties}

\section{Absorption spectroscopic studies}

The application of electronic absorption spectra in DNA-binding studies is one of the most useful techniques. The absorption spectra of the ligand and the $\mathrm{Ni}(\mathrm{II})$ complex in the absence and presence of CTDNA (at a constant concentration of complexes) are given in Fig. 2a. As can be seen from Fig. 2a, the Ni(II) complex exhibits an intense absorption band at 361 $\mathrm{nm}$ assigned to $\pi \rightarrow \pi^{*}$ transitions of the benzimidazole and picrate groups, and addition of increasing amounts (a)

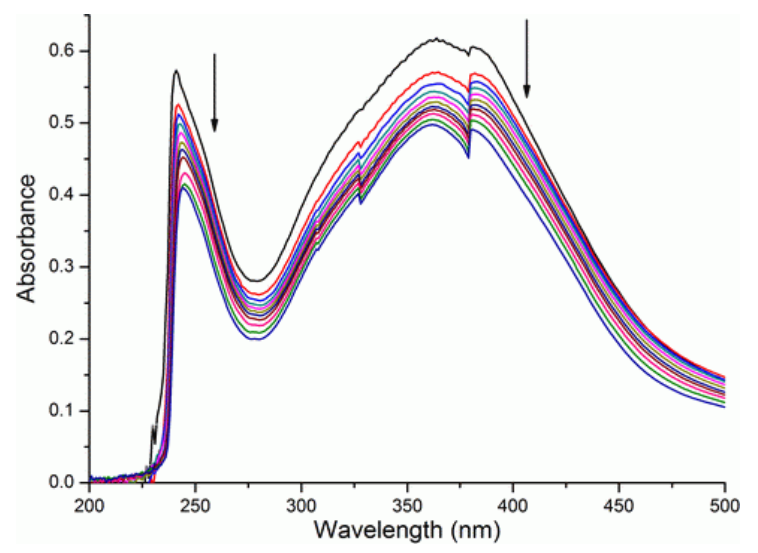

(b)

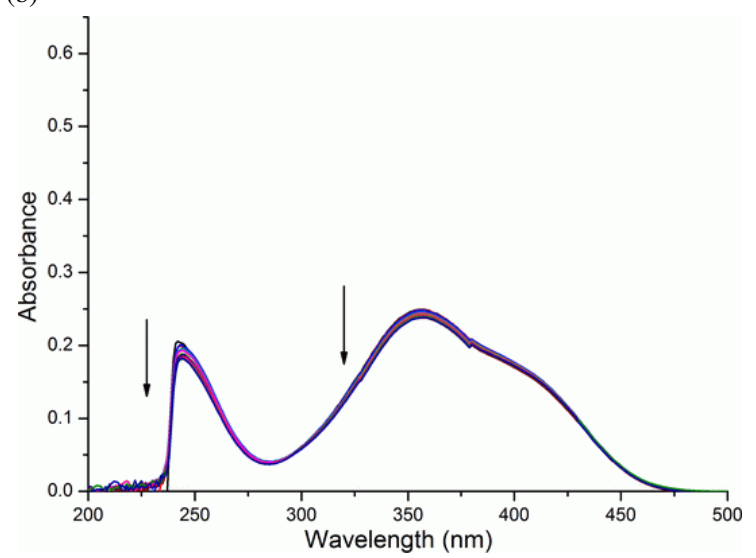

(c)

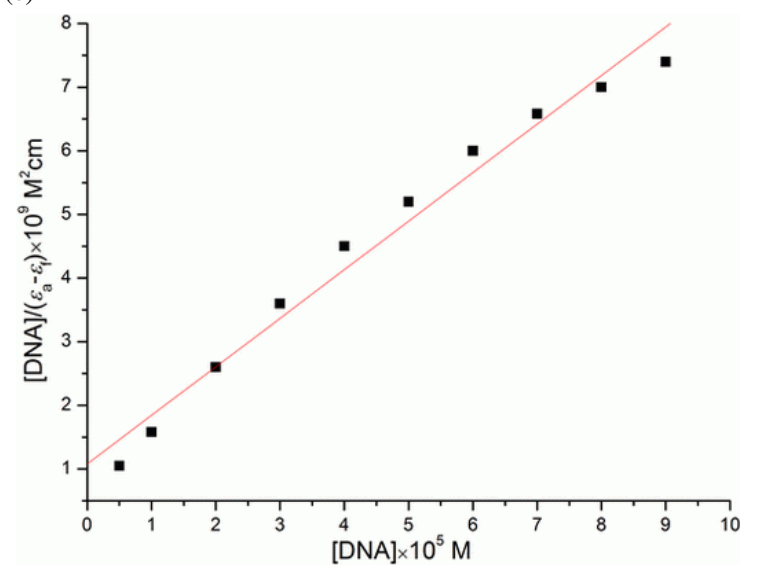

Fig. 2. Electronic spectra of the Ni(II) complex (a) and $\mathrm{Ni}(\text { pic })_{2}\left(\right.$ b) $\left(1.0 \times 10^{-5} \mathrm{M}\right)$ in the presence of $0,5,10$, $20,30,40,50,60,70,80$, and $90 \mu \mathrm{L} 2.5 \times 10^{-3}$ M CTDNA. Arrow shows the absorbance changes upon increasing the CT-DNA concentration. The plot of $[\mathrm{DNA}] /\left(\varepsilon_{\mathrm{a}}-\varepsilon_{\mathrm{f}}\right)$ vs. [DNA] for the titration of the Ni(II) complex with CTDNA (c); $\mathbf{a}$ : experimental data points; solid line: linear fitting of the data. 
of CT-DNA results in hypochromism in the UV/Vis spectra of the $\mathrm{Ni}(\mathrm{II})$ complex. In the present case, with addition of DNA, the $\mathrm{Ni}(\mathrm{II})$ complex exhibits hypochromism of about $19.4 \%$ and bathochromism of $1 \mathrm{~nm}$. These spectral characteristics suggest that the $\mathrm{Ni}(\mathrm{II})$ complex interacts with DNA, most likely through a mode that involves a stacking interaction between the aromatic chromophore and the base pairs [33,34]. As shown in Fig. 2b, Ni(pic) 2 exhibits hypochromism of about $4.4 \%$ and bathochromism of $1 \mathrm{~nm}$. It can assumed that the picrate anions bind to CT-DNA in a weak intercalation mode, and that the binding affinity of picrate anions is much weaker than that of the $\mathrm{Ni}$ (II) complex.

In order to further illustrate the binding strength of the Ni(II) complex, the intrinsic binding constant $K_{\mathrm{b}}$ was determined from the spectral titration data using the equation [23]

$$
[\mathrm{DNA}] /\left(\varepsilon_{\mathrm{a}}-\varepsilon_{\mathrm{f}}\right)=[\mathrm{DNA}] /\left(\varepsilon_{\mathrm{b}}-\varepsilon_{\mathrm{f}}\right)+1 / K_{\mathrm{b}}\left(\varepsilon_{\mathrm{b}}-\varepsilon_{\mathrm{f}}\right),
$$

where [DNA] is the concentration of DNA in base pairs and, the apparent absorption coefficients $\varepsilon_{\mathrm{a}}$, $\varepsilon_{\mathrm{f}}$ and $\varepsilon_{\mathrm{b}}$ correspond to $A_{\text {obsd }} /[\mathrm{M}]$, the extinction coefficient of the free compound and the extinction coefficient of the compound when fully bound to DNA, respectively. In plots of [DNA] $/\left(\varepsilon_{\mathrm{a}}-\varepsilon_{\mathrm{f}}\right) v s$. [DNA], $K_{\mathrm{b}}$ is given by the ratio of the slope to the intercept. From the [DNA] $/\left(\varepsilon_{\mathrm{a}}-\right.$ $\left.\varepsilon_{\mathrm{f}}\right) v s$. [DNA] plot (Fig. 2c), the binding constant $K_{\mathrm{b}}$ for the $\mathrm{Ni}$ (II) complex was estimated to be $7.07 \times 10^{4} \mathrm{M}^{-1}$ ( $R=0.9893$ for ten points).

\section{Fluorescence spectroscopic studies}

In order to further study the binding properties of the complex with DNA, competitive binding experiments were carried out. Relative binding of the Ni(II) complex to CT-DNA was studied by the fluorescence spectral method using ethidium bromide- (EB-) bound CT-DNA solution in Tris- $\mathrm{HCl} / \mathrm{NaCl}$ buffer $(\mathrm{pH}=7.2)$. Ethidium bromide (EB) is a weakly fluorescent compound, but in the presence of DNA its emission intensity is greatly enhanced because of its strong intercalation between the adjacent DNA base pairs. It was previously reported that the enhanced luminescence can be quenched by adding a second molecule [35,36].

A competitive binding of the $\mathrm{Ni}$ (II) complex to CTDNA resulted in the displacement of bound EB or in quenching of the bound EB, and as a consequence the emission intensity of ethidium bromide decreased. In

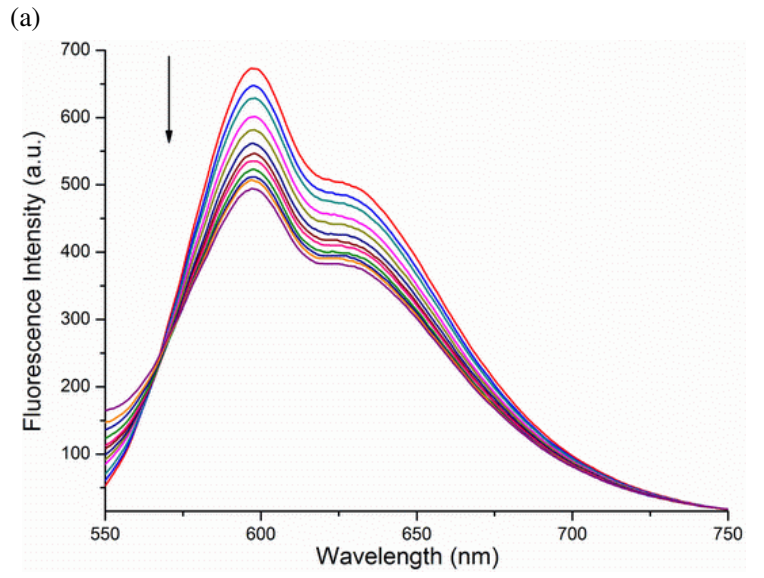

(b)

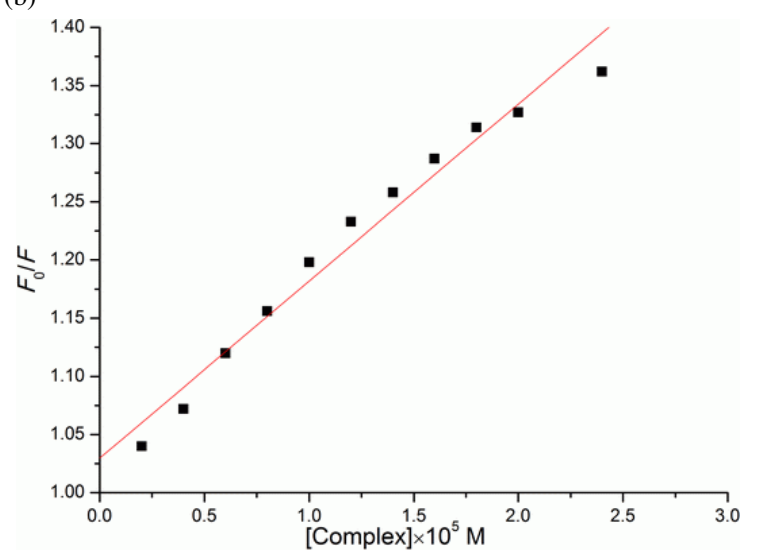

Fig. 3. Fluorescene spectra due to the binding of EB to DNA (a) in the absence and presence of increasing amounts of the $\mathrm{Ni}(\mathrm{II})$ complex, $\lambda_{\mathrm{ex}}=520 \mathrm{~nm},[\mathrm{~EB}]=8.8 \times 10^{-6} \mathrm{M}$, [CTDNA $]=1 \times 10^{-5} \mathrm{M}$. Arrow shows the absorbance changes upon increasing CT-DNA concentration. The Stern-Volmer quenching plot of $F_{0} / F v s$. [complex] for the titration of EB bound to CT-DNA by the Ni(II) complex (b); $\mathbf{m}$ : experimental data points; solid line: linear fitting of the data.

the competitive binding experiment, $10 \mu \mathrm{L}$ of a CTDNA solution was added to $10 \mu \mathrm{L}$ of an EB buffer solution ( $\mathrm{pH}=7.2$ ), and the fluorescence intensity was measured using the excitation wavelength of $520 \mathrm{~nm}$ resulting in an emission at about $600 \mathrm{~nm}$ at r. t.

Upon addition of the $\mathrm{Ni}$ (II) complex, the emission intensity of EB-bound calf thymus (CT-DNA) solution decreases, indicating that the complex competes with EB for binding with DNA (Fig. 3a). The extent of the reduction of the emission intensity gives a measure of the binding propensity of the complex to CT-DNA. According to the classical Stern-Volmer equation [35, 37]

$$
F_{0} / F=1+K_{\mathrm{sv}}[Q]
$$




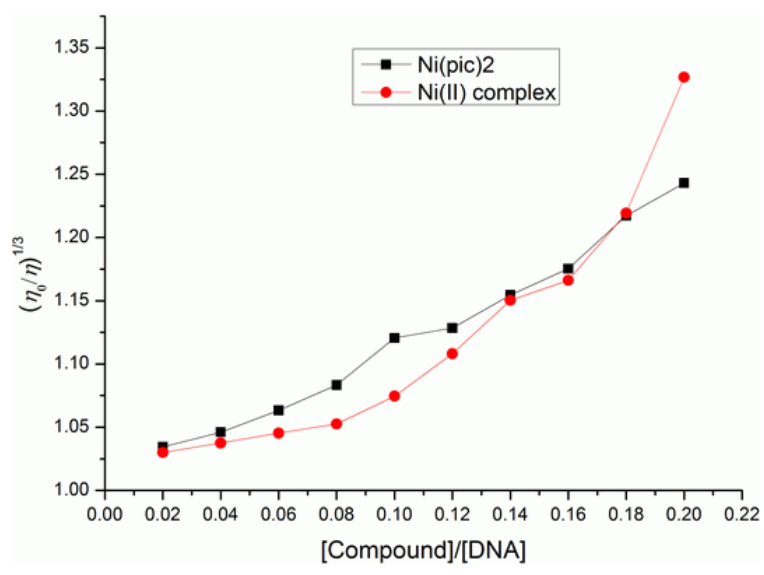

Fig. 4. Effects of increasing amounts of $\left[\mathrm{Ni}(\mathrm{bbp})_{2}\right]^{2+}(\mathbf{\square})$ and $\mathrm{Ni}(\mathrm{pic})_{2}(\bullet)$ on the relative viscosity of CT-DNA at $25 \pm$ $0.1^{\circ} \mathrm{C} ;[\mathrm{DNA}]=5 \times 10^{-5} \mathrm{M}$.

where $F_{0}$ is the emission intensity in the absence of the quencher, $F$ is the emission intensity in the presence of the quencher, $K_{\mathrm{sv}}$ is the quenching constant and $[Q]$ is the Ni(II) complex. The fluorescence quenching constant $\left(K_{\mathrm{SV}}\right)$ of the $\mathrm{Ni}(\mathrm{II})$ complex (Fig. 3b) is $1.52 \times$ $10^{4} \mathrm{M}^{-1}\left(R=0.9864\right.$ for eleven points). $K_{\mathrm{sv}}$ is a linear Stern-Volmer quenching constant dependent on the ratio of the bound concentration of EB to the concentration of DNA. It may be due to the $\mathrm{Ni}$ (II) complex interacting with DNA in partial intercalation mode, thereby releasing some free EB from the EB-bound CT-DNA complex system, which is consistent with the above absorption spectral result.

\section{Viscosity studies}

Optical techniques are widely used to study the binding model for combinations of the ligand, metal complexes and DNA, but give not always sufficient clues. Therefore, viscosity measurements were carried out to further clarify the interaction of the metal complex and DNA. Hydrodynamic measurements that are sensitive to the length change (i.e., viscosity and sedimentation) are regarded as the least ambiguous and the

[1] J. K. Barton, Science 1986, 233, 727-734.

[2] K. E. Erkkila, D. T. Odom, J. K. Barton, Chem. Rev. 1999, 99, 2777 - 2795.

[3] L. N. Ji, X. H. Zou, J. G. Lin, Coord. Chem. Rev. 2001, 216-217, 513-536.

[4] B. M. Zeglis, V.C. Pierre, J. K. Barton, Chem. Commun. 2007, $4565-4579$. most critical tests of a binding model in solution in the absence of crystal structure data [38,39]. With increasing amounts of the title $\mathrm{Ni}$ (II) complex, the viscosity of DNA increases steadily. The values of $\left(\eta-\eta_{0}\right)^{1 / 3}$ were plotted against [complex]/[DNA] (Fig. 4). In classical intercalation, the DNA helix lengthens as base pairs are separated to accommodate the bound ligand leading to increased DNA viscosity whereas a partial, nonclassical ligand intercalation causes a bend (or kink) in the DNA helix reducing its effective length and thereby its viscosity [39].

The effects of the $\mathrm{Ni}(\mathrm{II})$ complex and $\mathrm{Ni}(\text { pic })_{2}$ on the viscosity of CT-DNA are shown in Fig. 4. The viscosity of CT-DNA is increased steadily with the increment of the $\mathrm{Ni}$ (II) complex and $\mathrm{Ni}(\mathrm{pic})_{2}$, and it is further illustrated that the $\mathrm{Ni}(\mathrm{II})$ complex and $\mathrm{Ni}$ (pic $)_{2}$ intercalate with CT-DNA [39]. The results of the viscosity experiments confirm the mode of the Ni(II) complex intercalation into DNA base pairs already established through absorption and fluorescence spectroscopic studies.

\section{Conclusion}

In summary, a novel nickel(II) picrate complex based on the V-shaped ligand bbp has been synthesized and characterized. The results of a study of the interaction of this nickel(II) complex and of $\mathrm{Ni}$ (pic) $)_{2}$ with CT-DNA by using absorption and fluorescence spectral techniques and viscosity measurements suggest that the $\mathrm{Ni}(\mathrm{II})$ complex and $\mathrm{Ni}(\text { pic })_{2}$ bind to CTDNA in an intercalation mode, but the binding affinity of picrate anions is much weaker than that of the $\mathrm{Ni}$ (II) complex. The results could make a contribution to the design of pharmaceuticals on a molecular level.

\section{Acknowledgement}

The authors acknowledge the financial support and a grant from 'Qing Lan' Talent Engineering Funds. The grant from the Middle-Young Age Science Foundation (grant no. 3YS061-A25-023) and 'Long Yuan Qing Nian' of Gansu Province is also acknowledged.

[5] J. Mann, A. Baron, Y. Opoku-Boahen, E. Johansson, G. Parkinson, L. R. Kelland, S. Neidle, J. Med. Chem. 2001, 44, 138 - 144.

[6] J. Cheng, J. T. Xie, X. J. Luo, Bioorg. Med. Chem. Lett. 2005, 15, 267-269.

[7] A. Gellis, H. Kovacic, N. Boufatah, P. Vanelle, Eur. J. Med. Chem. 2008, 43, $1858-1864$. 
[8] Ö. Ö. Guven, T. Erdogan, H. Goker, S. Yildiz, Bioorg. Med. Chem. Lett. 2007, 17, 2233-2236.

[9] H. Torres-Gomez, E. Hernandez-Nuez, I. Leon-Rivera, J. Guerrero-Alvarez, R. Cedillo-Rivera, R. Moo-Puc, R. Argotte-Ramos, M. C. Rodriguez-Gutierrez, M. J. Chan-Bacab, G. Navarrete-Vazquez, Bioorg. Med. Chem. Lett. 2008, 18, 3147-3151.

[10] S. M. Sondhi, S. Rajvanshi, M. Johar, N. Bharti, A. Azam, A. K. Singh, Eur. J. Med. Chem. 2002, 37, $835-843$.

[11] L. J. K. Boerner, J. M. Zaleski, Curr. Opin. Chem. Biol. 2005, 9, $135-144$.

[12] V. G. Vaidyanathan, B. U. Nair, J. Inorg. Biochem. 2002, 91, 405-412.

[13] V. G. Vaidyanathan, B. U. Nair, J. Inorg. Biochem. 2003, 93, 271-276.

[14] V. G. Vaidyanathan, B. U. Nair, J. Inorg. Biochem. 2003, 94, $121-126$.

[15] V. G. Vaidyanathan, B. U. Nair, Eur. J. Inorg. Chem. 2003, $3633-3638$.

[16] J. L. Wang, L. Shuai, X. M. Xiao, Y. Zeng, Z. L. Li, M.-I. Takeko, J. Inorg. Biochem. 2005, 99, 883 - 885.

[17] J. Marmur, J. Mol. Biol. 1961, 3, $208-218$.

[18] M. F. Reichmann, S. A. Rice, C. A. Thomas, P. Doty, J. Am. Chem. Soc. 1954, 76, 3047-3053.

[19] T. B. Chaires, N. Dattaguota, D. M. Crothers, Biochem. 1982, 21, 3933-3940.

[20] A. Wolf, G. H. Shimer, Jr., T. Meehan, Biochem. 1987, 26, $6392-6396$.

[21] A. W. Addison, P. J. Burke, J. Heterocycl. Chem. 1981, $18,803-805$.

[22] S. X. Wang, Y. Cui, R. X. Tan, Q. H. Luo, J. Q. Shi, Q. J. Wu, Polyhedron 1994, 13, $1661-1668$.

[23] X. J. Xu, Z. X. Xi, W. Z. Chen, D. Q. Wang, J. Coord. Chem. 2007, 60, 2297-2308.
[24] RAPID-AUTO, Rigaku/MSC, The Woodlands, Texas (USA) 2004.

[25] G. M. Sheldrick, SHELXTL, Siemens Analytical X-Ray Instruments, Inc., Madison, Wisconsin (USA), 1996. See also: G. M. Sheldrick, Acta Crystallogr. 1990, A46, 467 -473; ibid. 2008, A64, 112 - 122.

[26] W. J. Geary, Coord. Chem. Rev. 1971, 7, 81-122.

[27] W. J. Zhang, W.H. Sun, S. Zhang, J.X. Hou, K. Wedeking, S. Schultz, R. Fröhlich, H. B. Song, Organometallics 2006, 25, 1961 - 1969.

[28] N. M. Aghatabay, A. Neshat, T. Karabiyik, M. Somer, D. Haciu, B. Dülger, Eur. J. Med. Chem. 2007, 42, $205-213$.

[29] Z.Z. Yan, Y. Tang, M. Y. Tan, W. S. Liu, D. Q. Wang, Acta Chim. Sinica 2007, 65, 607-614.

[30] H. L. Wu, R. R. Yun, K. T. Wang, K. Li, X. C. Huang, T. Sun, Z. Anorg. Allg. Chem. 2010, 636, 629-633.

[31] H. L. Wu, R. R. Yun, K. T. Wang, K. Li, X. C. Huang, T. Sun, Y. Y. Wang, Z. Anorg. Allg. Chem. 2010, 636, $1397-1400$.

[32] W. Rosen, D. H. Busch, Inorg. Chem. 1970, 9, $262-$ 265.

[33] J. K. Barton, A. T. Danishefsky, J. M. Goldberg, J. Am. Chem. Soc. 1984, 106, $2172-2176$.

[34] S. A. Tysoe, R. J. Morgan, A. D. Baker, T. C. Strekas, J. Phys. Chem. 1993, 97, 1707-1711.

[35] J. R. Lakowicz, G. Webber, Biochem. 1973, 12, 4161 4170.

[36] B. C. Baguley, M. LeBret, Biochem. 1984, 23, $937-$ 943.

[37] M. R. Efink, C. A. Ghiron, Anal. Biochem. 1981, 114, $199-206$.

[38] S. Satyanarayana, J.C. Dabroniak, J.B. Chaires, Biochem. 1992, 31, 9319-9324.

[39] S. Satyanaryana, J.C. Daborusak, J.B. Chaires, Biochem. 1993, 32, $2573-2584$. 